is hardly likely to enter into competition with ordinary electroplating for large work or for irregular articles. Nor is it likely to be employed in cases where heavy coatings of metal are required, because it would not be an easy matter to rub on sufficiently evenly to obtain uniform and thick deposits.

F. M. P.

\section{UNIVERSITY COLLEGE, LONDON.}

Appeal for New Chemical Laboratories.

$\mathrm{M}^{\mathrm{A}}$

ANY old students of University College, London, and others familiar with the work done in the chemical department of the college, will be interested in the appeal which has just been made for funds for new chemical laboratories.

The letter which Lord Rosebery has written as Chancellor of the University, and the statement circulated by Sir Henry Roscoe, as chairman of the Equipment and Endowment Fund Chemistry Appeal Committee, serve to bring into high relief the urgent need at University College for improved and more extensive accommodation in its chemical department, both for teaching and research purposes.

While, thanks largely to the generosity of $\mathrm{Mr}$. Carnegie, the University of Manchester has recently become possessed of adequate and modern laboratories, and fine building possessing admirable accommodation for chemical science have been erected at South Kensington-to give two examples only-the University College laboratories date from 187 I. Yet, despite material disadvantages, splendid work for chemistry has been accomplished in Gower Street under Graham, Williamson, Sir William Ramsay, and others.

In America to mention the need and to state the sum required would ensure its being immediately forthcoming, especially when it can in a sense be regarded as a means of celebrating the completion by Sir William Ramsay of twenty-one years of work at University College. In Germany, again, the State would see to it that so distinguished a chemist was not hampered by want of material or accommodation.

We are hopeful that a ready response to the appeal will be promptly forthcoming, and that very soon the necessary buildings will be in course of erection. The appeal, and Lord Rosebery's letter referring to it, are subjoined.

An Appeal for $70,000 l$. for the purchase of a Site and the erection of new Chemical Laboratories thereon at University of London, University College.

The chemical laboratories at University College, London, were for the most part built under the direction of the late Prof. Alexander Williamson in the year $187 \mathrm{r}$. From time to time they have been re-fitted and supplemented to meet the demands of the subject and the increasing number of students in the department. It has been impossible in the present buildings of the college to provide the requisite additional accommodation in rooms immediately adjoining the main laboratories. Consequently, at the present time the department is scattered and inconvenient, and neither in planning nor equipment is it adequate for modern chemistry work. The average number of students in the chemical department for the last four sessions has been 261 , of whom, on the average, 160 have been students in the junior classes, 68 students in the advanced laboratories, and 33 research students.

During the last four sessions, the college has been compelled to refuse students for want of room, even after making such arrangements as have been possible for the laboratory work of some students elsewhere. The number of those who desire to do research work under Sir William Ramsay and Prof. Collie has also increased to such an extent that additional accommodation is now a matter of urgent necessity.

The lack of adequate accommodation for the department of chemistry at the college has been carefully considered by the University and college authorities, and the conNo. $2 \mathrm{IO}_{3}$, VOL. 82$]$ clusion has been arrived at that nothing short of entirely new buildings can meet the necessities of the case, a conclusion confirmed by the Treasury Commissioners at their last inspection of the college, and also by the University inspectors.

The provision of new buildings for the department of chemistry will greatly benefit other branches of university study now hampered for want of room. The space in the present buildings vacated by the department of chemistry will go some way towards supplying the deficiency of space for other subjects.

It was originally proposed to provide the requisite accommodation for chemistry by erecting the north-west wing of the college on the Gower Street frontage, but a more convenient site has been found fronting Gower Place on the north side of the present buildings of the college. This site has a frontage of about 316 feet and an average depth of 66 feet, with a superficial area of about 20,800 feet, and is suitable in every way for the erection of chemical laboratories. The Senate has acquired an option lasting for a short period to buy this site at an agreed price.

The erection of the north-west wing of the college would necessarily be expensive, because it nust be built in Portland stone and correspond in elevation with the remainder of the quadrangle of which it would form part, and for these reasons it would not be suitable for chemical laboratories. It is estimated that the cost could not be less than $70,000 l$.

For this sum $(70,000 l$.) not only could the freehold of the proposed new site be acquired, but a suitable building for the department of chemistry could also, it is estimated, be erected upon it.

If sufficient money is not immediately forthcoming to complete the whole scheme, the earlier subscriptions will be applied in purchasing the site.

The services to chemical science which have been rendered by Sir William Ramsay, the university professor of general and inorganic chemistry, who has recently completed twenty-one years' work at the college, and the important discoveries that he has made, are generally well known. In addition to these, the number of researches published during the past twenty-two years by members of the staff and students of the chemical department amounts to 331 ; of these, 72 have been carried out by Sir William Ramsay and collaborators. It is interesting to observe that while the total number of researches published from the department from $1887-1902$ was II5, the number issued since 1902 , when the laboratories were enlarged, to the present year is already 216 .

It is the wish of Sir William Ramsay's friends and of his old students to see his desire for adequate and wellequipped chemical laboratories realised as speedily as possible.

This appeal for $70,000 l$. for new chemical laboratories is therefore made to all who are interested in the advance of chemical science, and also to all who desire to see university teaching in London developed in accordance with its needs.

Donations or subscriptions, which may be paid in instalments, should be sent to the chairman or the treasurer of the new chemical laboratories fund, and addressed to University College, London.

Henry E. Roscoe (Chairman).

Letter from the Chancellor of the University. Dalmeny House,

Edinburgh.

January 23 , 1910.

I earnestly hope that the friends of the University of London and the admirers of Sir William Ramsay will cooperate to ensure the success of this appeal for $70,000 l$. for an academical necessity.

Should the admirers of Sir William Ramsay alone take the matter up in proportion to their zeal and his merits, there can be no doubt of the necessary fund being raised.

But indeed those who are interested in the well-being of our university, either from their association with it or on high public grounds, will, I am sure, spare no effort to ensure the prompt erection of the chemical laboratories so urgently needed for its work.

ROSEBERY (Chancellor). 